References

I Roberts, J L and Pritcheti, D (1984) Trends NeuroSct 7, 105-107

2 Mason, A J. Evans, B A, Cox, D R Shine, J and Richards, R I (1983) Nature (London) 303, 300-307

3 Owen, M C, Brennan, S O, Lewis, J H and Carrell, R W (1983) N Engl J Med 309, 694-698

4 Brennan S $O$ and Carrell, R W (1978)
Nature (London) 274, 908-909

5 Abdo, Y, Rousseaux. J and Dautrevaux M (1981) FEBS Lett 131, 286-288

6 Mdgnusson, S (197!) in The Enzymes, Vo III Hydrolysts, Pepttde bonds (Boyer P D, ed ), 3rd edn, pp 277-321, Academic Press, New York and London

7 Kassell, B and Kay, J (1973) Science 180 1022-1027

8 Juvenal Satures o 347
9 Geller. D M . Judah, 1 (1) and Nicholk M R (1972) Brochem f 127,865-874

10 Docherty, $K$ and Steiner $D$ \& $\left\{19 k_{2}\right\}$ Annu Rev Physiol 44, 625-638

11 Green, D P L (1984) Med Hvpotheser is $47-611$

1) P L GREFN

Department of Pharmacology, University of Otago, PO Box 913, Dunedin. New Zealand

\title{
Reviews
}

\section{The unique origin of rod photoreceptors in the teleost retina}

\section{Pamela A. Raymond}

A population of mutonc cells that produce new neurons has recently been discovered in the layer of photoreceptors in retinas of several spectes of larval and adult fish These cells generate new rods which are inserted into the photoreceptor mosaic at locations scattered across the entire expanse of the differentiated retina. Subsequently these new rods establish synaptc connections with retinal neurons already present. The continued production of rods in the fish is apparently needed to maintain visual sensittvity during postembryonic growth of the eye.

The extent of postembryonic growth and neurogenesis in the retina and brain of many species of adult teleost fish has only recently been widely appreciated $^{1}$ This is somewhat surprising since the first thorough documentation of retinal cell addition in adult fish was provided over thirty years ago by Mūller ${ }^{2}$, who counted cells and calculated the total number of neurons in the retınas of guppies (Lebistes reticulatus) from hatching to adult stages As the fish grew from $7 \mathrm{~mm}$ to $28 \mathrm{~mm}$ long he found a threefold increase in the number of gang lion cells, cones and inner nuclear layer cells, and nearly a sevenfold increase in numbers of rods More recent studies in juvenıle and adult goldfish, as well as other related species (Carassius spp.), have used cell counts ${ }^{3,4}$, optic fiber counts ${ }^{5}$ and autoradiographic techniques ${ }^{6,78}$ to confirm that new neurons are added to the retina as the fish grows Most postembryonic neuronal cell addition in the retına takes place in a narrow circumferential geminal zone that is located at the peripheral margin $2,6,8$

\section{Neurogenesis is not restricted to the germinal zone}

However, it has been discovered recently that not all neurogenesis in the teleost retina is confuned to the circumferential germinal zone Sandy and Blaxter ${ }^{9}$ found that when $\left[{ }^{3} \mathrm{H}\right]$ thymıdine was injected into metamorphos- ing herning and sole, scattered cells in the outer nuclear layer, among the nuclel of photoreceptors, incorporated the label. Simular dividing cells were found in larval and juvenile goldfish and also in a cichlid fish (Haplochromis burtoni), in fish allowed to survive for a few weeks or months after the thymidine injection, labeled nuclei of rods, but no other neurons, were seen in the central retina ${ }^{7,10}$. Thus, whereas production of most neurons in the postembryonic teleost retina is confined to the circumferentıal edge, new rods contınue to be produced by a dispersed population of rod precursors in central regions of the retina which have already differentrated and become functional (Fig 1)

The demonstration that new rods are produced by mitotic division within the differentiated teleost retına provided an explanation for some puzzling observations that had been made repeatedly by several investigators but had been difficult to interpret Pnnc1pal among these was the observation that in many species of teleost fish the larval forms initially have no rods, but only cones ${ }^{11}$. Rods begin to appear either at metamorphosis or sometime durıng larval development, depending on the species, they then start to accumulate so that their proportions slowly but persistently increase during larval and/or postlarval stages of growth $^{2} 3.7$ An especially dramatic example of this persistent addition of rods in the adult teleost retina was described by Locket $^{12}$ in a deep-sea fish, Chauliodus sloant. The retinas of mature fish of this species contain no cones but only rods, which are arranged in tiers, or banks, in small specimens there is one tier, but in larger animals, there are up to five tiers (Fig 2)

\section{Discovery of the rod precursor}

It is now clear that dividing rod precursors are responsible for the delayed and prolonged production of rods in the teleost retina ${ }^{7.9}$ Previous attempts to explain the sudden appearance of rods in the differentiated larval retına and the persistent accumulation of new rods in the postlarval retına were unsatisfactory and, in retrospect, somewhat contrived. It was suggested, for example, that cones were transformed into rods ${ }^{13}$ or that cells migrated out of the inner nuclear layer into the outer nuclear layer where they differentiated $n$ to $\operatorname{rod} s^{11}$, or that rods were produced in the circumferentıal germinal zone but were then displaced laterally into more central regions of the retina ${ }^{2.6}$ The possibılity that mitotic division of stem cells within the differentiated retina might account for the addition of new rods did not seem to be an acceptable alternative because at that time there was little evidence for mitotic actıvity anywhere except at the germinal zone

The finding that mitotically active cells give rise to new neurons withın fully differentıated regions of retına was totally unanticipated It contradicted all previous conceptions of how retinal histogenesis might be organlzed. To date most studies have observed that in the developing retina cytogenesis and differentiation take 

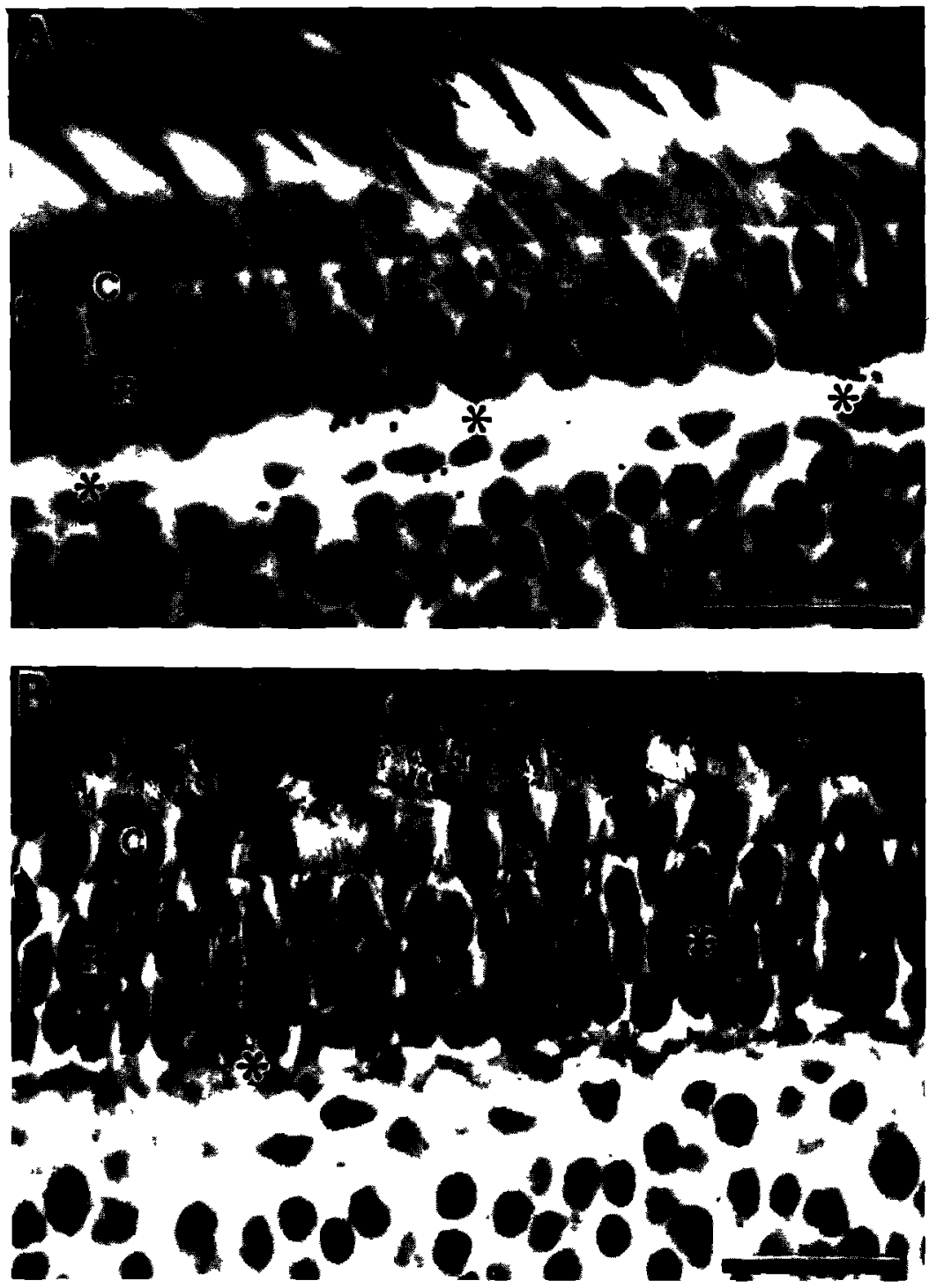

Fig. 1. A. Dividing rod precursors in the retina of a juvenule goldfish [ $\left.{ }^{3} H\right]$ Thymidine was injected $4 \mathrm{~h}$ before the antmal was sacnfied and the retina was prepared for autoradiography Three heavily labeled nuclet (astersked) are at the base of the outer nuclear layer among the spindle-shaped nuclei of differentiated rods $(R)$, cone nuclet $(C)$ are lighter and peanut-shaped and lie in a single stratum above the rod nuclet, at the level of the external liminng membrane (arrow) Cahbrahon bar $s 20 \mu m \mathbf{B}$. Labeled rod nuclei in the retna of a juvenile goldfish This fish was injected with $\left.{ }^{3} H\right]$ thymidine 20 days prior to sacrifice Rod precursors incorporated the label, then divided and their progeny (still labeled) differentuated into rods (astersked) Note that labeled rod nuclet are dispersed through all levels of the outer nuclear layer from the base to the external lminng membrane (arrow) Cone nuclet (C) were never labeled except in association with the circumferential germinal zone Calibration bar is $20 \mu \mathrm{m}$

(Reprinted with permission from Johns, 1982)

place in a stnctly centrifugal fash$10 n^{2.14}$. In the early presumptive retına, neuroepithelial germinal cells across the entire retınal epithelium are actively dividing; cell differentiation commences in the central region, near the ongin of the optic nerve. As differentiation progresses, more and more cells differentiate, and the postmitotic region enlarges centrifugally toward circumferential germinal zone of the postembryonuc retina ${ }^{7}$. This scheme not only provides an inherently consistent and simple explanation for the observed pattern of concentric cell addition at the perimeter of the growing retinas in these anımals, but it also fosters a strong bias against the idea that mitosis might occur elsewhere, such as in the central regions of the retina Furthermore, the central retına appears to be made up of differentiated neurons arranged in well organızed lamınae, whereas the cells in the circumferential germinal zone look very much like the neuroepithelial cells of the embryonic retına Both of these considerations tended to support the belief that postembryonic neurogenesis must be restricted to the germinal zone

The nature of the rod precursor probably also accounts, in part, for the falure to recognize these cells until recently The dividing rod precursors are not very different in overall nuclear size or in light microscopic staınıng charactenstics from the mature rod nucles that surround them (They can be distinguished with electron microscopy, however; this is discussed later) They are diffusely scattered across the retina, and in juvenile goldfish, for example, they compnse only about $0.5 \%$ of the total rod population ${ }^{7}$. Because of their scattered distribution and scarcity, their discovery required that somehow they be marked or labeled to set them apart from the differentiated rod nuclei around them. $\left[{ }^{3} \mathrm{H}\right]$ Thym1dine, which is incorporated into the nuclei of mitotically active cells, provided an ideal marker. Though occasıonal reports of mitotic activity in the outer nuclear layer had appeared in the literature before 1980 (cited in Ref $9)$, these were largely ignored.

Dividing rod precursors have recently been identified in the larval goldfish retına usıng thymidine autoradıography at the electron microscopic level, and several labeled precursors have also been reconstructed from serial thin sections ${ }^{15}$ The nucleus of the rod precursor usually, though not always, lies at the base of the outer nuclear layer, adjacent to the outer plexiform layer, a neuropil region where synaptic contacts are made between mature photoreceptors (both rods and cones) and second-order neurons Rod nuclei are located in the same stratum as the precursors, whereas nucleı of cones are more apically positioned, at the level of the external lımıting membrane (Fig. 1) Rod pre- 
cursors are typically pear-shaped, with a thin apically-directed process that approaches but does not reach the external limitıng membrane (Fig. 3). This is an important observation because it shows that rod precursors are not equivalent to neuroepithelial cells in the germinal zone (see below). The rod precursors are sometimes grouped in clusters of five to 10 cells, entwined in a tight spiral ${ }^{15}$ At other times, they are found singly or in pairs An interesting feature of the shape of these cells is the presence of lateral fins or ridges which extend about $1 \mu \mathrm{m}$ from the somata, their function is unknown

\section{What are rod precursors?}

Rod precursors do not fit into the classic scheme of retinal histogenesis Retinal histogenesis is essentrally similar in all vertebrates and can be simply but quite accurately thought of as an orderly and sequential partitioning of the prumitive neuroepithelium into three cellular layers ${ }^{14,16}$. Prmitive neuroepithelial cells are spindleshaped and maintain an attachment to

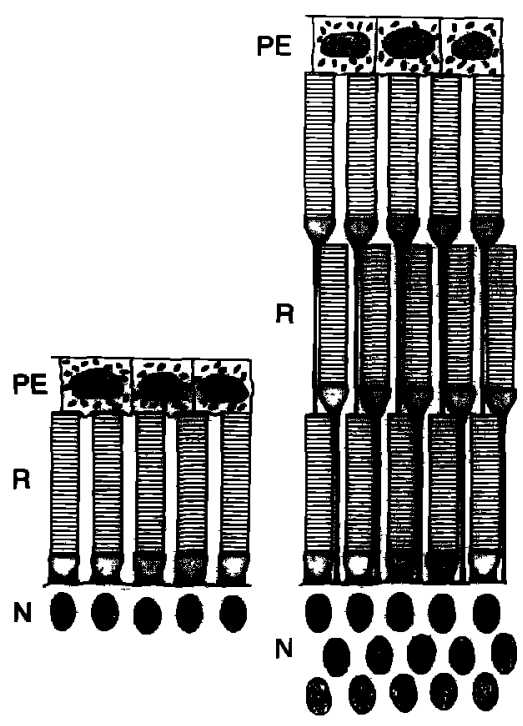

Flg. 2. Dugram to show the addution of new thers of rods during postembryonic growth of the fish, Chauliodus sloany Small specumens (29 to $36 \mathrm{~mm}$ standard body length exclusive of tall) have one row or her of rods $(R)$, as shown on the left Rods consist of a cylundrical outer segment (striped) contanung vusual pigment on top of a spheroudal inner segment (gray) contauning mostly mitochondria The long slender attachment of the inner segments to the rod nuclei $(N)$ is difficult to resolve in the light microscope and is omitred from the diagram The pigmented eputhelum (PE) is at the top of the figure Larger specimens (120 10 $192 \mathrm{~mm}$ standard body length) have three thers of rods and three rows of rod nuclet, as shown on the right Even larger spectmens have four or five thers (Adapted from Locket, 1980) the apical (ventricular) surface (In the retına, the external limitıng membrane is homologous to the ventricular surface ) The basal process of the cell is withdrawn during mitosis as the nucleus migrates to the apical surface to divide ${ }^{17}$ (Fig. 4A and B) This to and fro movement of the nucleus is called 'Interkinetic nuclear migration' When a neuroepithelial cell completes its terminal mitotic divısion, it loses its cytoplasmic attachment to the apical surface and, now a young neuron, it migrates basally to settle in its appropnate laminar position (Fig 4B) The innermost, or most basal layer, is always the first to form, it becomes the ganglion cell layer of the mature retina The photoreceptors in the outermost layer, the outer nuclear layer, are typically the last neurons to be born, that is, to cease dividing ( $F_{1 g}$ 4C). According to this scheme all retinal neurons are denved from neuroepithelial cells As pointed out above, however, the rod precursors are not part of this primitive layer, which has dispersed by the time that production of rods commences (Fig $4 \mathrm{C}$, D) Moreover, rod precursors do

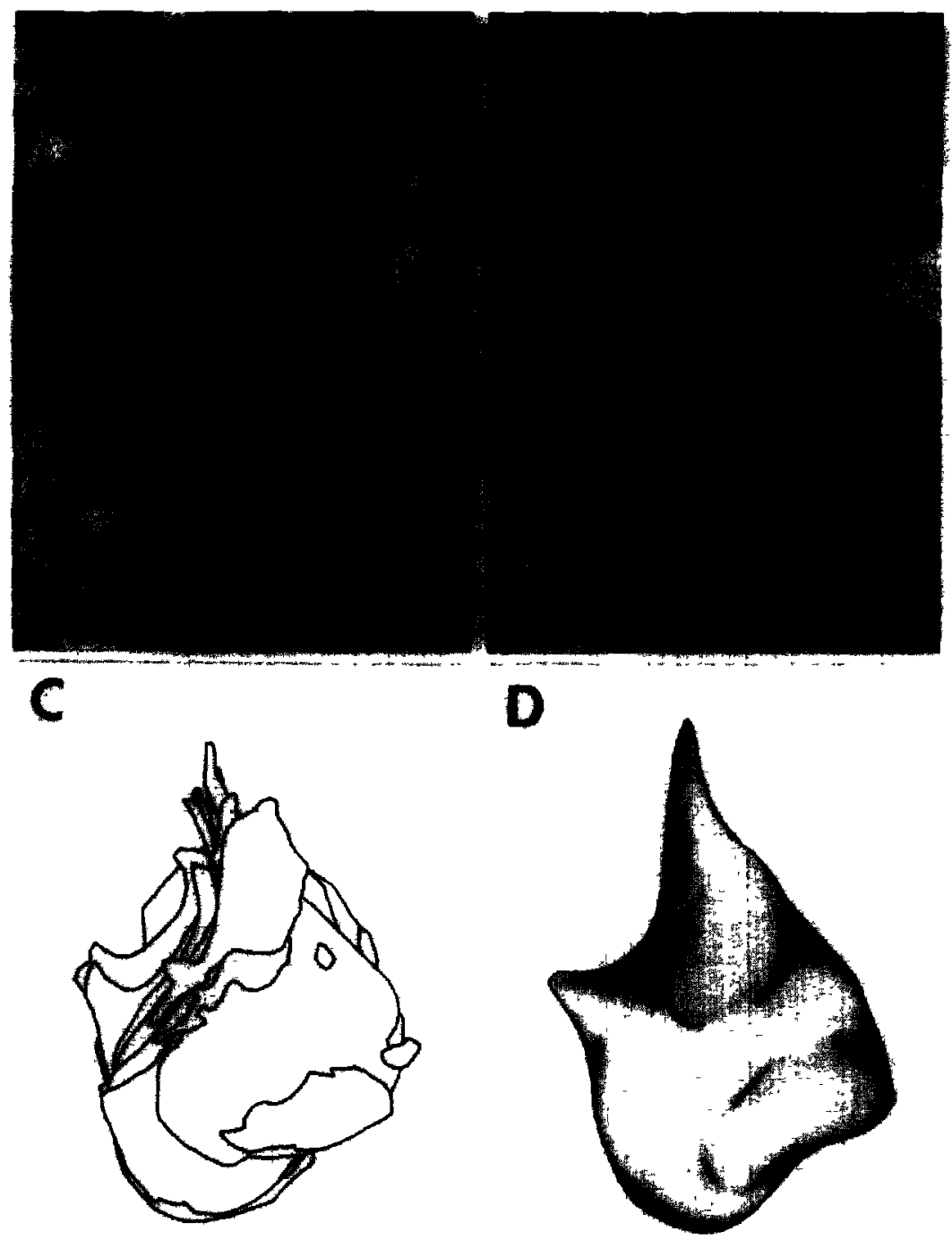

Fig. 3. Morphology of rod precursors Dividing rod precursors were labeled by injecting a 26-day-old goldfish with $1 \mu \mathrm{Cl}$ of [3H]thymidine Serial thin sections were prepared and every 20th section th the sertes was processed for both autoradiography and electron microscopy

A. a labeled rod precursor (arrow) Calibration bar, $2 \mathrm{wn}$ B. the same cell in another section from the senal set, not processed for autoradiography C. a three-dimensional reconstruction of this cell generated by a computer graphics program from digutized tracings of every fifth section Cahbration bar, $2 \mu \mathrm{m}$ D. an artsit's rendinon of the cell (A, B and C reprinted with permission from Raymond and Rivlın 1984 ) 
not exhibit at least two of the most characteristic features of neuroepithelial germinal cells (1) they are not attached to the apical surface, and (ii) their nuclei do not show interkınetic migration It seems, then, that rods in the teleost retına derive from a uniquely specialized precursor cell, not previously described in other developing vertebrate retınas

Although not part of the accepted pattern of neurogenesis in the retına, there is a precedent for neuronal production by cell division outside the ventricular zone (as the primitive neuroepithelium is sometımes called ${ }^{17}$ ) in other parts of the vertebrate CNS In some regions of the developing brain, notably in the cerebellum and the hippocampal formation, a secondary zone of neurogenesis called the subventricular zone forms when some of the cells in the ventrcular zone migrate away from the ventricular surface ${ }^{17}$ Subventricular cells, like rod precursors, divide in situ and are responsible for the formation of certain late-generated neurons, such as the granule cells of the dentate gyrus and the cerebellar cortex The evidence is consistent with the notion that rod precursors constitute a kind of subventncular zone within the retina, but the retınal subventricular zone differs from other such zones as it is not a separate and distinct layer but instead a scattered collection of cells dispersed among mature neurons
The origin of the rod precursors is ultimately the neuroepithelium of the presumptive embryonic retina or the circumferential germinal zone of the growing postembryonic retına (Fig 5). The steps involved in the production of new retına at the growing margin of the postembryonic eye recapitulate the stages of histogenesis in the embryonic and larval retına 2.7 . Here we consider only the formation of the photoreceptor layer. The outer nuclear layer is intially composed of a single layer of postmitotic but immature cone nuclei $7,9,18$ and the rod precursors are nowhere to be found Only after the cones begin to differentiate, do the rod precursors appear at the base of the outer nuclear layer (Fig 4C); untıl that time they are sequestered in the inner nuclear layer, and they must migrate across the developing outer plexiform layer to reach their final position $^{7}$ Migration of cells from inner to outer nuclear layers in the developing teleost retina had been suggested previously as a mechanism to explain the delayed appearance of rods $^{11}$, though at that time it was not realized that the migrating cells were dividing rod precursors A better known example of migration of immature cells from one retınal lamina to another has been described by Hinds and Hınds ${ }^{19}$, who suggested that at least some amacrine cells in the developing mouse retina are transiently located in the ganglion cell layer and then migrate across the inner plexiform layer to reach their definitive location in the inner nuclear layer where they complete their differentiation In this case, however, the migrating cells are postmitotic

The rod precursor appears to be dedicated to the production of one and only one class of neuron, rods This conclusion derives from examınation of retınas after long term thymidine labelıng, in which the only labeled cells in the central retina are rods ${ }^{7}$. The apparent specificity of rod precursors is a unıque ontogenetıc character It is generally believed that germınal cells of the CNS are homogeneous and pluripotent and give rise sequentially to several different types of neurons and eventually even to glia ${ }^{17}$, but recent evidence, presented by Rakic and colleagues $^{20,21}$, has cast doubt on this interpretation With immunocytochemical techniques they probed the nature of the neuroepithelium at the molecular level and found that there is more than one population of germınal cells: some cells stained positively for antıbodies to a glial-specific marker, glial fibrillary acidic protein (GFAP) but others were unstained. They interpreted this as evidence that separate glial and neuronal lineages coexist in the ventricular zone (see Ref 22 for a different view) If we extend this idea to the rod precursor in the teleost retina, we might postulate that it represents a further specialization of the

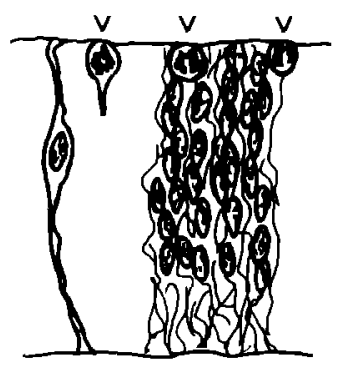

A

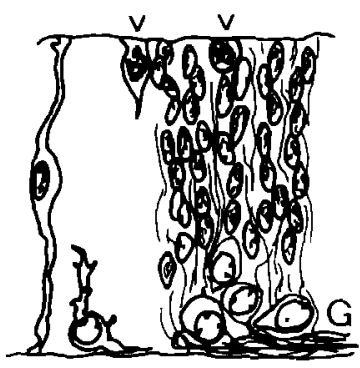

B

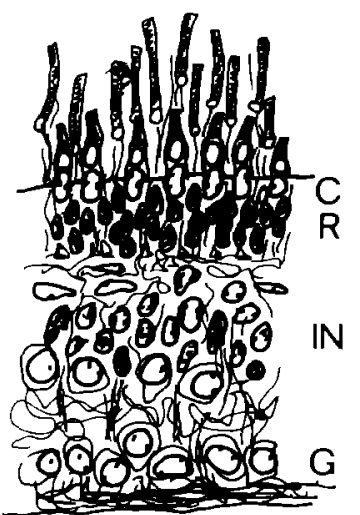

D

Fig-4. Retnal histogenests A. The prumitive retnal epuhelium is a homogeneous sheet of dividing neuroepuheltal cells These are spindle-shaped cells which typically span the width of the epithelum, as shown by the tsolated cell on the lefi During mutosts the basal process is withdrawn, the nucleus moves to the apical surface and the cell rounds up to divide (arrowheads) B. The first neurons to differentiate are invariably ganglion cells (G) As a young neuron leaves the mutotic cycle it detaches from the apical surface and the nucleus moves down the basal process unhl it reaches the appropriate level, which for the ganglion cells is next to the inner (basal) surface While the nucleus is still migrating an axon begins to grow out, as can be seen in the isolated cell at center left C. With further development the cells of the neuroepthelum are partitoned into the three definitive strata of the differentiated retina, the ganglion cell layer $(G)$, the inner nuclear layer (IN), and the outer nuclear layer (ON) In teleost fish and also in primates, rods are at first under-represented in the layer of photoreceptor nuclet (the outer nuclear layer) At this early stage, the outer nuclear layer consists of a single row of immature cone nuclet, a few small dark nuclet at the base of the cones are presumed to be rods (in the primate retina) or are known to be rods and rod precursors (in the fish retina) This drawing equally well depicts the fetal primate retna ${ }^{14} 24$ or the larval teleost retana 9,18 D In the mature teleost retuna there is a single row of cone nuclet (C) and multiple rows of rod nuclet $(R)$ in the outer nuclear layer (The spectes of fish depicted in Fig 2 is an exception) A simular situanon holds in non-foveal regions of the mature primate retna 
neuroepthelial cell, and if so, the teleost retına might offer a convenient model in which to study questions related to cell lineage and cell determınation in the developing nervous system.

\section{The role of rod precursors}

Just how unique are the rod precursors and what is the purpose of persistent generation of rods in the postembryonic teleost retına? The fact that rods in the teleost retina are the last neurons to be born is not unusual Carter-Dawson and LaVall ${ }^{23}$ have shown that in the developing mouse retina production of rods begins later and lasts longer than production of cones Thus the sequence and timıng of photoreceptor production is qualitatively similar in fish and mammals and may reflect a general, though perhaps not universal, pattern of retinal histogenesis.

An even more intnguing companson can be made between developing rods and cones in pnmate and teleost retınas In pnmates, as in fish, the outer nuclear layer can first be recognized as a single row of postmitotic nuclei that differentiate into cones $^{14.24}$ The row of cones is separated from the incipient Inner nuclear layer, which stıll contains undifferentiated neuroepithelial cells, by a narrow fibrous zone, the presumptive outer plexıform layer Rod nucleı later accumulate beneath the developing cone nuclei, and it is implicitly assumed that the immature rods migrate across the outer plexiform layer from the inner nuclear layer where they are temporarily sequestered Thymidine studies have yet to be done, so it is not known when rod production by mitosis ceases nor whether the rod progenitors continue dividing after they cross the outer plexiform layer and enter the outer nuclear layer It is entirely possible that a rod precursor like the one described here might also exist at least temporarily in the developing primate retuna

However, fish are clearly different from mammals as their retina contınues to grow and add new cells throughout life Eastest to understand is the cell proliferation which occurs at the circumferential germinal zone, where production of new neurons is least likely to interfere with ongoing neural function ${ }^{2}$ More difficult to comprehend is the insertion of new rods into the mosaic of differentiated photoreceptors in central regions

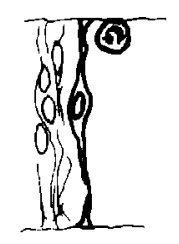

\section{neuroepithelial} cells

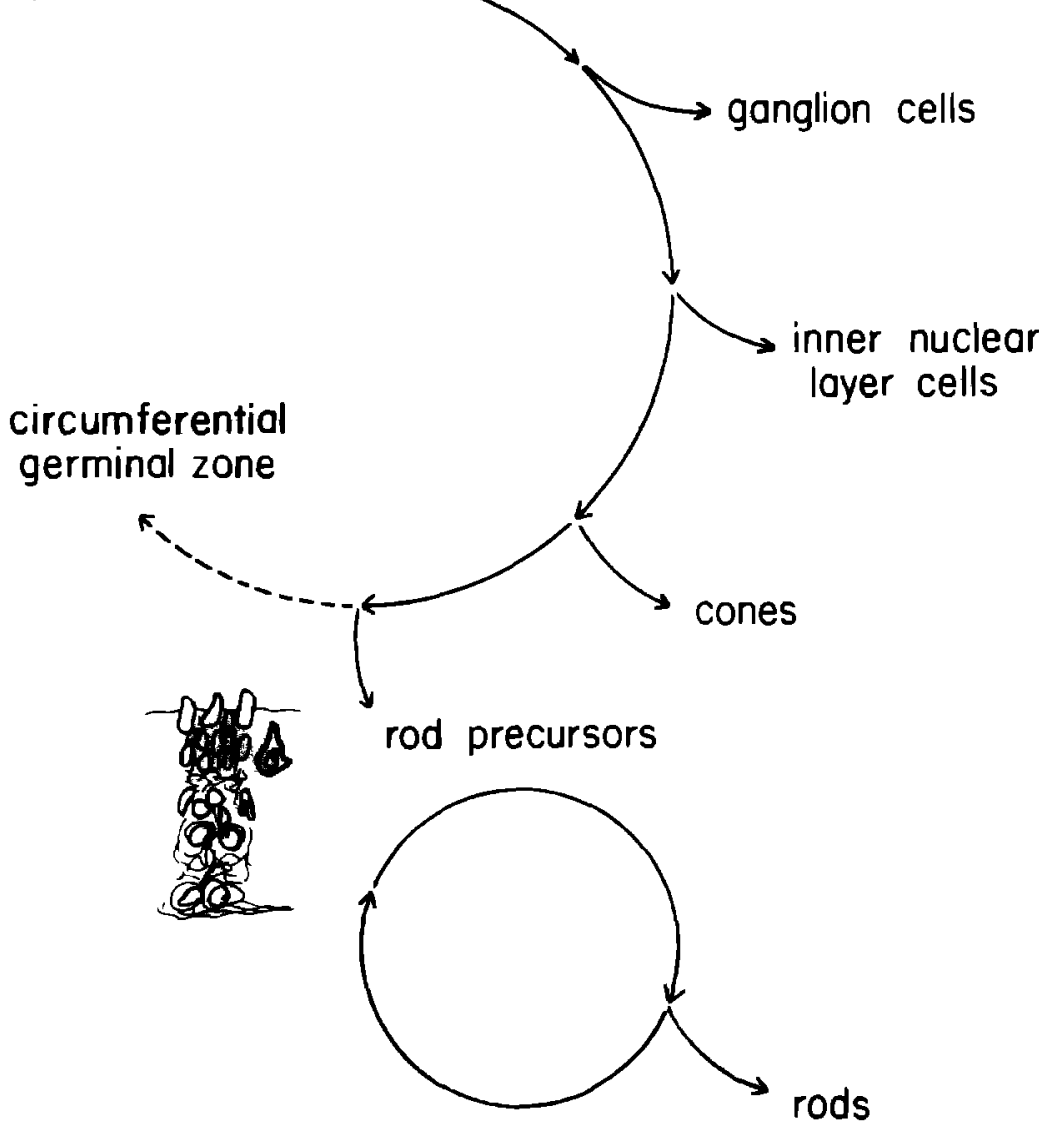

Fig. 5. Duagram to show the ontogeneth hustory of teleost retanal neurons From the primuve neuroepithelial cells are produced gangluon cells, unner nuclear layer cells, cones and rod precursors. The remnants of the neuroepithelial populaton persist in the circumferental germinal zone, which continues to produce retinal neurons in the adult fish. The rod precursors constitue on independent prollferanng population that gives rise exclusively to rods

Why is such an apparently disruptive activity necessary? Part of the growth of the teleost retina is due to expansion or stretching of the retinal surface with an accompanying decrease in the density of cells per unit area ${ }^{2,3}$. The rods are the only exception: density of rods increases during postembryonic growth (Fig. 6) For example, by the time a goldfish is about a year old the rod precursors have built up the rod population to a density of about 200000 rods $\mathrm{mm}^{-2}$ of retinal surface From then on production of new rods continues at a rate only sufficient to maintain this density, as the forces of expansion pull the rods apart ${ }^{3,7}$ Thus the goal of rod proliferation appears to be related to the generation and main- tenance of a high density of rods as the retina expands The motive force underlying postembryonic expansion of the retinal surface is unknown, but may be related to the intraocular pressure. Whatever the mechanism, it is a universal property of the vertebrate eye, which enlarges postembryonically in all species ${ }^{14}$, though by varying amounts.

Recently Stell and Kock ${ }^{25}$ have provided a direct demonstration that new rods added in the adult goldfish are integrated into the retinal circuitry They showed by serial sectioning of identified, Golgi-impregnated cells that the number of rods connected to each $b 1$ bipolar cell (a particular type of second-order neuron which contacts 
every rod that falls within its dendritic domain) increased by $50 \%$ as goldfish grew from about six months to five years of age. Synaptogenesis contınues at higher-order levels of processing, too. In the inner plexiform layer, where bipolar and amacrine cells synapse onto ganglion cells, the density of synapses $\mathrm{mm}^{-2}$ of retinal surface increases by about $30 \%$ during growth of adult goldfish from about one to four years of age $\mathrm{e}^{26}$

There is little reason to doubt, then, that the new rods are functional, but what is the effect of continued addition of rods on the visual behavior of the fish? Powers and Bassi27 have attempted to answer this question by measuring the absolute visual threshold in goldfish of various sizes. (The absolute visual threshold is defined as the minımum intensity of light needed for detection by a fully dark adapted eye.) The larger fish required only slightly more photons incident at the retina to detect a light; the small increase was directly proportional to the calculated increase in neural noise due to the extra rods. Thus, nearly constant visual sensitivity is maintained during growth of the adult goldfish eye while millions of new rods are added. Though a causal relation has not been proven, the inference that rod addition is required to maintain sensitıvity seems plausible

It is interesting that the cones do not follow the same strategy as the rods. New cones are added with retinal growth, but only at the marginal germinal zone, and thus the density of cones, measured in number $\mathrm{mm}^{-2}$, in central regions of retına decreases ${ }^{2,3,13}$ When measured as density of cones visual degree $^{-2}$, however, the density increases as the eye enlarges This is a consequence of the fact that the lens grows in direct proportion to the retina, therefore the retinal magnification factor ( $\mu \mathrm{m}$ retınal surface subtended-degree visual angle ${ }^{-1}$ ) also increases, in other words, the image formed on the retına by a given stımulus is larger, more magnified, in large goldfish eyes compared to smaller ones ${ }^{28}$ Intuitıvely, then, the 'grain' of the cone mosaic can be allowed to become coarser in larger retinas, $1 \mathrm{e}$ the cone density (in number $\mathrm{mm}^{-2}$ ) can decrease, without sacrificing resolving power Visual acuity has been measured behaviorally as a function of size in a few teleost species $29,30,31$ and the results consistently show an increase in acuity with growth just as predicted

The prolonged penod of rod genesis

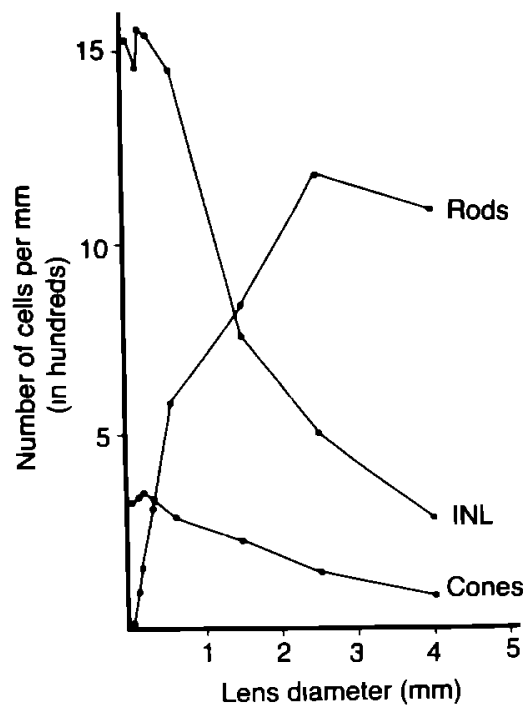

Fig. 6. The linear densty of cells in the retina of postembryonic goldfish The number of cells $\mathrm{mm}^{-1}$ of rennal length is plotted as a function of the diameter of the lens in $\mathrm{mm}$ In eyes from small fish, one sample was taken from the center of the retina in each of three meridional sections, in larger eyes, four to six samples equally spaced across the renna were counted in one mertdonal section The data plotted are means of courts from two to five eyes in each of eight successtve, non-overlapping ranges of lens diameter from less than 01 10 $40 \mathrm{~mm}$ The fish ranged in age from newly hatched larvae to 4- and 5-year-old adults INL, cells in the inner nuclear layer (Repnnted with permission from Johns, 1982 )

in the teleost retına and the formation of a special precursor population of dividing cells within the retina therefore appears to be necessitated by the conditions imposed by the process of postembryonic growth, especially the stretching or expansion of the retinal surface The continued insertion of new rods into the photoreceptor mosaic and the formation of new synaptic connections as the new rods become incorporated into the retinal circuitry is another example ${ }^{1}$ of the remarkable degree of plasticity that is part of the normal growth process in these animals

\section{Acknowledgements}

The author has previously published under the name Pamela $\mathbf{R}$ Johns. The work reported from this laboratory was supported by PHS grant EY04318 and NSF grant BNS8203268 The author is also the rec1pient of a Sloan Research Fellowship from the Alfred P Sloan Foundation Patricia K Ruvlin helped prepare the figures Stephen $S$ Easter, $\mathrm{Jr}$ offered his usual insightful comments on the manuscript, which Sharon Moskwiak and Barbara France typed
Selected references

1 Easter, S S (1983) Trends Neurosa 6.5356

2 Muller, H (1952) Zool Jahrb 63, 275-324

3 Johns, P R and Easter, S S (1977) $J$ Comp Neurol 176, 331-342

4 Kock, J H (1982) J Comp Neurol 209. 264-274

5 Easter, S S, Rusoff, A C and Kısh, P E (1981) $J$ Neurosca 1, 793-811

6 Johns, P R (1977) J Comp Neurol 176, 343-358

7 Johns, P R (1982) J Neuroscl 2, 179-198

8 Meyer, R L (1978) Exp Neurol 59, 99-111

9 Sandy, J M and Blaxter, J H S (1980) J Mar Biol Assoc UK 60, 59-71

10 Johns, P R and Fernald, R D (1981) Nature (London) 293, 141-142

11 Blaxter, J H S (1975) in Vision in Fishes New Approaches in Research (Al, M A, ed ), pp 427-444, Plenum Press. New York

12 Locket, N A (1980) Proc $R$ Soc London Ser $B$ 208, 223-242

13 Lyall, A H (1977) $Q J$ Microsc Sct 98, 189-201

14 Mann. I (1964) The Development of the Human Eye Grune and Stratton, New York

15 Raymond, P A and Rıvlın, P K (1984) in Proceedings of the 42nd Annual Meeting of the Electron Microscopy Society of America (Barley, G W , ed ), pp 724-725, San Francisco Press, San Francisco

16 Hinds, J W and Hinds, P L (1974) Dev Biol 37, 381-416

17 Boulder Committee (1970) Anat Rec 166. 257-262

18 Branachek, T and BreMiller, R (1984) $J$ Comp Neurol 224, 107-115

19 Hinds, J W and Hinds, P L (1978) $J$ Comp Neurol 179, 277-300

20 Levitt, P and Rakic, P (1981) J Neurosct 1, 27-39

21 Levitt, P, Cooper, M L and Rakic, P (1983) Dev Bıol 96, 472-484

22 DeVitry, F, Picart, R, Jacque, C, Legault, L , Dupouey, P, Tixier-Vidal, A (1980) Proc Natl Acad Sci USA 77, 4165-4169

23 Carter-Dawson, L D and LaVall, M M (1979) J Comp Neurol 188, 263-272

24 Hollenberg. M J and Spira, A W (1972) Can J Ophthalmol 7, 472-491

25 Stell, W K and Kock, J H (1983) in Molecular and Cellular Basis of Visual Acuity Seventh Sympasium on Ocular Development (Sheffield, J B and Hilfer, S R , eds), pp 79-105, Springer-Verlag, New York

26 Fisher, L J and Easter, S S (1979) $J$ Comp Neurol $185,373-379$

27 Powers, M K and Bassı, C J (1981) Neuroscl Abstr 7,541

28 Easter, S S , Johns, P R and Bauman. L R (1977) Vision Res 17, 469-477

29 Baerends, G P, Bennema, B E and Vogelzang, A A (1960) Zool Jahrb 88 , 67-78

30 Rahmann, H , Jeserich, G and Zeutzıus. I (1978) Behaviour 68, 315-322

31 Hairston, N G , Li, K T and Easter, S S (1982) Science $218,1240-1242$

$\overline{\text { Pamela A Raymond is Assistant Professor at the }}$ Department of Anatomy and Cell Btology, University of Michtgan Medical School, Ann Arbor, MI 48109-0010, USA 